\title{
KOMUNIKASI PEMASARAN UNTUK PROGRAM PEMBINAAN REMAJA MASJID
}

\author{
Listi Nur Aziansyah \\ STID Al-Hadid, Surabaya \\ listinura@gmail.com
}

\begin{abstract}
Abstrak: Remaja Masjid (Remas) merupakan tempat pembinaan bagi remaja muslim. Namun saat ini Remas cenderung sepi peminat. Dewan Masjid Indonesia pun menilai regenerasi remaja masjid sangat dibutuhkan di Indonesia. Diketahui salah satu sebab sepinya Remas karena minimnya informasi tentang kiprah Remas, sehingga remaja muslim ada yang berpersepsi Remas tidak menarik. Untuk menjawab hal itu, melalui studi ini dibuatkan komunikasi pemasaran program pembinaan Remas dengan pendekatan model AIDA. Tujuannya untuk menjadi referensi bagi Remas atau lembaga dakwah lain dalam melakukan komunikasi pemasaran program pembinaannya kepada remaja muslim. Studi ini merupakan penelitian dasar (basic research) dengan pendekatan kualitatif pustaka. Hasil studi menunjukan bahwa sebenarnya remaja muslim membutuhkan program pembinaan Remas, karena kondisi mereka sedang dalam proses pencarian jati diri, meneliti sikap hidup dan standar moral yang benar, dan ingin mendalami ajaran Islam yang telah diyakini. Hal ini perlu dikomunikasikan kepada remaja muslim dengan menggunakan pendekatan AIDA yaitu mengomunikasikan sesuai dengan tahapan respons yang akan dilalui. Dimulai dengan disadarkan bahwa mereka membutuhkan program pembinaan Remas sekaligus menjawab persepsi tentang Remas (Attention), kemudian diberi tahu tentang deskripsi dan manfaat serta analisis terjawabnya kebutuhan remaja muslim oleh program pembinaan Remas (Interest dan Desire), diakhiri dengan ajakan untuk mengikuti program pembinaan Remas (Action).
\end{abstract}

Kata kunci: Komunikasi Pemasaran Model AIDA, Program Remaja Masjid, Remaja Muslim.

Marketing Communication For Remas Guidance Program. Abstract: REMAS is a guidance place for Moslem teenagers. However, REMAS tends to have lack of participants. Dewan Masjid Indonesia also assess that REMAS regeneration is needed in Indonesia. A lack of REMAS progress information is one of the causes of its lack of participants. It results in their perception that REMAS is not interesting. To respond the problem, through this study, a marketing communication for REMAS guidance program has been developed with AIDA approach. It aims to be a reference for REMAS or other da'wah institutions in conducting marketing communication for Moslem teenagers' guidance program. This basic research uses qualitative literature approach. It indicates that Moslem teenagers actually need this program since they are finding their self-identity, examining the right life attitude and moral standards, and wanting to know more about Islam. These problems need to be communicated to them by using AIDA, namely communicating the matters through response stages. It starts from triggering the awareness on the need of REMAS guidance program and answering their perception about REMAS (Attention). Then, they need to get 
information about description, benefits and analysis on answering their needs through the program (Interest and Desire). And finally, they need to join the program (Action).

Key words: AIDA Marketing Communication model, program of Remaja Masjid (REMAS), Moslem Teenagers.

\section{Pendahuluan}

Sejak awal didirikan oleh Rasulullah saw, masjid memiliki peran yang penting dalam membangun peradaban umat muslim. ${ }^{1}$ Masjid tidak hanya difungsikan sebagai "tempat sujud" sebagaimana makna harfiahnya, tetapi multifungsi. Pada masa Rasulullah saw, masjid juga difungsikan sebagai sentra kegiatan-kegiatan pendidikan, yakni tempat pembinaan dan pembentukan karakter umat. ${ }^{2}$ Hingga kini, masjid juga menjadi tempat sentral pembinaan umat bagi masyarakat di Indonesia. Semua peribadatan dan dakwah islamiyah umat berpusat dan dimulai dari masjid. Bahkan keberadaan masjid pun sangat mudah untuk ditemukan. ${ }^{3}$

Salah satu objek yang prospek untuk dibina oleh masjid adalah kelompok remaja. Hal itu karena remaja memiliki kondisi fisik yang sehat serta daya pikir terutama kreativitas yang tinggi, yang semuanya ini merupakan

\footnotetext{
1. Syamsul Kurniawan, "Masjid dalam Lintasan Sejarah Umat Islam", Jurnal Khatulistiwa - Journal of Islamic Studies 04, no. 02 (2014) : 169, doi: $10.24260 /$ khatulistiwa.v4i2.258

2. Ibid.

3. Agus Susanto, Keputusan Stratejik Program Open Recruitment Remaja Masjid Al Akbar Surabaya 20142016 (Tesis Program Pascasarjana, UIN Sunan Ampel, Surabaya, 2017), 1.

4. Prasetio Rumondor dan Puspasari M. Y. Gobel, “Pola Pembinaan Kepribadian dan Keagamaan Remaja Masjid Al-Fatah Di Kelurahan Girian Indah Kecamatan Girian Kota Bitung", Al-lzzah: Jurnal Hasil-Hasil Penelitian 14, no. 2 (2019), 7, doi: http://dx.doi.org/10.31332/ai.v14i2.1525.

5. Ibid, 8.
}

potensi yang sangat besar untuk diarahkan dalam kontribusi pembangunan masyarakat Islam. ${ }^{4}$ Adapun wadah khusus yang dibentuk oleh masjid untuk pembinaan akidah, akhlak, ukhuwah, keilmuan, dan keterampilan remaja muslim adalah Remaja Masjid atau biasa disebut Remas. ${ }^{5}$

Namun kegiatan Remas cenderung kurang diminati pemuda muslim, ${ }^{6}$ sehingga organisasi remaja masjid kian hari kian memudar. $^{7}$ Juru bicara Dewan Masjid Indonesia Muhammad Novar Akbar mengatakan bahwa regenerasi remaja masjid di seluruh Indonesia perlu menjadi perhatian bersama umat Islam. ${ }^{8}$ Sejauh ini hanya beberapa Remas di Indonesia yang telah aktif dan berkembang, diantaranya Masjid Agung Sunda Kelapa Jakarta (Riska), Masjid Cut Mutia Jakarta (Ricma), Masjid Al Azhar Jakarta (YISC Al-Azhar) dan Masjid AtTin Jakarta (Prisma At-Tin). Di luar Jakarta, ada misalnya Masjid Al Latif di Bandung

\footnotetext{
6. Indah Wulandari, "Menyiasati yang Muda Agar Giat di Kelompok Remaja Masjid", Republica.co.id, 24 Februari, 2015, https://www.republika.co.id/berita/nk9ig1/menyiasat i-yang-muda-agar-giat-di-kelompok-remaja-masjid. (diakses tanggal 15 Januari, 2021).

7. Agung Sasongko, Manajemen Remaja Masjid akan Diperkuat, Republica.co.id, 18 Maret, 2019, https://www.republika.co.id/berita/pojx2×313/manaj emen-remaja-masjid-akan-diperkuat. (diakses tanggal 15 Januari, 2021).

8. Hasanul Rizqa, "DMI Luncurkan Program 1 Kelurahan 1 Remaja Masjid", Republika.co.id, 18 Maret, 2019, https://republika.co.id/berita/pojgap458/dmiluncurkan-program-1-kelurahan-1-remaja-masjid. (diakses tanggal 15 Januari, 2021).
} 
dengan komunitas Pemuda Hijrah dan Masjid Jogokaryan di Yogyakarta. ${ }^{9}$ Ini mengindikasikan masih banyak Remas yang perlu diaktifkan guna menjalani fungsinya sebagai wadah pembinaan dakwah islamiyah bagi remaja muslim.

Salah satu sebab sepinya Remas adalah kekeliruan persepsi remaja terhadap Remas. Citra Remas bagi remaja dipandang sebagai tempat yang tidak menarik, karena hanya ada salat, ngaji dan agama-agama saja, mereka merasa ada tempat yang lebih gaul dan menyenangkan, daripada harus diceramahi kalau ikut Remas. ${ }^{10}$ Padahal dalam Keputusan Direktur Jenderal Bimbingan Masyarakat Islam Nomor 948 Tahun 2018 tentang Pedoman Pembinaan Remaja dan Pemuda Masjid Bab IV Standar Aktivitas, diketahui bahwa kegiatan Remas tidak hanya berisikan ritual dan spiritual saja melainkan juga berfokus pada bidang intelektual (wawasan keilmuan), sosial (aksi dan kepedulian sosial), dan juga minat dan bakat (pengembangan potensi remaja dan pemuda masjid). ${ }^{11}$ Sehingga persepsi yang menganggap Remas hanya berisikan kegiatan agama saja adalah salah.

Bahkan ada Remas yang tidak diketahui bagaimana kiprahnya sehingga remaja

\footnotetext{
9. Ibid.

10. "Ubah Citra Remaja Masjid", Republika.co.id, 21 November, 2014 https://www.republika.co.id/berita/koran/halaman1/14/11/21/nfdhw99-ubah-citra-remaja-masjid.

(diakses tanggal 6 Agustus, 2018).

11. Subdit Kemasjidan, "Pedoman Pembinaan Remaja Masjid", SIMAS - Sistem Informasi Masjid, 19 Juni, 2020,

https://simas.kemenag.go.id/page/download/detail/5 eebbfe6d3b78. (diakses tanggal 14 Januari, 2021). 12. Najmi Syakib, Pembinaan Keagamaan Bagi Remaja Melalui Aktivitas Remaja Masjid Dalam Menumbuhkan Sikap Toleransi Antar Umat Beragama
}

muslim tidak tahu bahwa ada remaja masjid. ${ }^{12}$

Rendahnya minat remaja muslim untuk mengikuti kegiatan pembinaan Remas tentu menjadi masalah. Karena mengingat tujuan dibentuknya Remas, ${ }^{13}$ maka seharusnya Remas mampu mengundang minat remaja muslim untuk mengikuti kegiatan pembinaan Remas. Remas diharapkan mampu menjadi salah satu ujung tombak kegiatan dakwah di kalangan remaja, dengan menyampaikan nilai-nilai Islam kepada remaja sehingga dapat diterapkan dalam kehidupan di masyarakat. ${ }^{14}$

Dari gejala masalah, diketahui bahwa rendahnya keminatan remaja muslim terhadap Remas berhubungan dengan minimnya informasi remaja muslim terkait Remas. Akibatnya mereka tidak mengetahui tentang Remas, ${ }^{15}$ dan ada juga yang berpikiran negatif tentang Remas. ${ }^{16}$

Untuk mengatasi persoalan tersebut, maka digunakan pendekatan teori komunikasi pemasaran model AIDA (Attention, Interest, Desire, Action). AIDA merupakan salah satu bentuk dari teori Hirarki Efek, ${ }^{17}$ yang menyatakan bahwa setiap konsumen akan melawati tahapan kognisi (belajar), afektif

(Skripsi Program Sarjana, UIN Sultan Maulana Hasanuddin, Banten, 2019), 46.

13. Rumondor, Pola Pembinaan, 8.

14. Nabed Nuwairah, "Peran Keluarga dan Organisasi Remaja Masjid Dalam Dakwah Terhadap Remaja", Al Tadzkiyyah - Jurnal "Al-Hiwar 03, no. 06 (2015), 10, doi: http://dx.doi.org/10.18592/al-hiwar.v3i6.1211

15. Syakib, Pembinaan Keagamaan, 46.

16. NN, Ubah Citra Remaja Masjid.

17. Diah Syafita Johar, Srikandi Kumadji, dan M. Kholid Mawardi, "Pengaruh AIDA (Attention, Interest, Desire, Action)", Jurnal Administrasi Bisnis 26, No. 1 (2015), 2, doi:

https://media.neliti.com/media/publications/86248ID-pengaruh-aida-attention-interest-desire.pdf 
(merasakan), hingga perilaku (bertindak). ${ }^{18}$ Dalam model AIDA, tahap kognisi berisikan proses Attention (menarik perhatian), tahap afeksi berisikan proses Interest (mempertahankan minat) dan Desire (merangsang kemauan), dan tahap perilaku yang berisikan proses Action (mendorong terjadinya tindakan pembelian). ${ }^{19}$ Dengan menggunakan komunikasi pemasaran AIDA, diharapkan muncul ketertarikan remaja muslim untuk mengetahui informasi tentang Remas dan mendalami program pembinaan Remas, sehingga ketidaktahuan dan kekeliruan persepsi mereka terhadap Remas dapat terjawab. Dengan begitu diharapkan akan muncul dorongan untuk mengikuti program pembinaan Remas.

Komunikasi pemasaran memang memegang peranan penting dalam pemasaran karena seperti halnya yang dialami oleh Remas dimana kegagalan pemasaran terjadi bukan karena kualitas produk tapi kesalahan persepsi calon konsumennya. ${ }^{20}$

Beberapa studi terdahulu yang membahas tema sejenis, yaitu pertama, jurnal yang ditulis oleh Moh. Farid Najib, dkk berjudul Peningkatan Kapasitas Lembaga Melalui Pengembangan Komunikasi Pemasaran Guna Mendorong Minat Donatur Dalam Berdonasi Pada Istana Yatim Dhu'afa. ${ }^{21}$ Dari studi tersebut diketahui bahwa dengan mengembangkan komunikasi pemasaran

18. Rahmat Sholeh, Proses Hierarchy of Effect Model Dalam Komunikasi Pemasaran (Skripsi Program Sarjana, UIN Sunan Kalijaga, Yogyakarta, 2018), 20.

19. Johar, Pengaruh AIDA, 5.

20. Ibid., 8.

21. Moh. Farid Najib, Deddy Saefuloh, Iwan Mulyawan, Eddy Syah Yahya, dan Tjetjep Djatnika, "Peningkatan Kapasitas Lembaga Melalui Pengembangan Komunikasi Pemasaran Guna Mendorong Minat Donatur Dalam Berdonasi Pada Istana Yatim Dhu'afa", Jurnal DIFUSI 3, no. 1 (2020) : 17-29, doi: https://doi.org/10.35313/difusi.v3i1.1946 dapat meningkatkan minat donatur terhadap Yayasan Istana Yatim Dhu'afa. Adapun persamaannya yaitu membahas komunikasi pemasaran dan efeknya terhadap keminatan objek sasaran di konteks organisasi nirlaba. Sedangkan perbedaannya yaitu objek pemasaran tidak spesifik remaja muslim dan bukan diterapkan pada organisasi Remas.

Kedua, jurnal yang ditulis oleh Subhan Afifi dan Muhammad Edy Susilo yang berjudul Pengembangan Komunikasi Pemasaran Sekolah. ${ }^{22}$ Studi ini menjelaskan pentingnya komunikasi pemasaran bagi sekolah, agar siswa tertarik dan terbentuk branding sekolah yang bermanfaat untuk jangka panjang. Adapun kesamaannya yaitu membahas komunikasi pemasaran untuk meningkatkan keikutsertaan objek sasaran. Namun bedanya adalah objeknya bukan Remas dan remaja muslim.

Ketiga, jurnal yang ditulis oleh Rina Duwi Jayanti yang berjudul Penyusunan Desain Instruksional pada Pelatihan Anggota Remaja Masjid Assalafiyah Surabaya. ${ }^{23}$ Tujuan dari studi tersebut adalah membuat desain pelatihan anggota Remas Assalafiyah Surabaya dalam proses pelayanan penerimaan dana zakat dengan pendekatan teori desain instruksional. Diketahui bahwa persamaannya adalah di objek yaitu Remaja Masjid. Namun secara perbedaan diketahui

22. Subhan Afifi dan Muhammad Edy Susilo, "Pengembangan Komunikasi Pemasaran Sekolah", Jurnal Ilmu Komunikasi 13, no. 3 (2014) : 277-286. https://doi.org/10.31315/iik.v12i3.1446

23. Rina Duwi Jayanti, "Penyusunan Desain Instruksional Pada Pelatihan Anggota Remaja Masjid Assalafiyah Surabaya", Jurnal Inteleksia - Jurnal Pengembangan Ilmu Dakwah 01, no. 02 (2020), 261-279, doi: http://www.inteleksia.stidalhadid.ac.id/index.php/int eleksia/article/view/53 
bahwa fokus masalahnya adalah pelatihan SDM Remas bukan tentang strategi promosi Remas.

Dari beberapa studi terdahulu dapat disimpulkan belum ada studi yang membahas tentang komunikasi pemasaran Remas kepada remaja muslim. Sedangkan diketahui dari latar belakang bahwa Remas mengalami masalah pada komunikasi pemasaran. Akhirnya, program-program Remas yang cenderung bermanfaat dan menarik bagi remaja pun tidak terkomunikasikan. Padahal jika Remas mampu mengambil peran dalam pembinaan karakter remaja maka potensi remaja dapat terarahkan menjadi lebih baik. Maka rumusan masalah yang perlu dijawab adalah bagaimana komunikasi pemasaran program pembinaan Remas kepada remaja muslim dengan menggunakan pendekatan AIDA. Tujuan dibuatnya studi ini adalah untuk menghasilkan rumusan komunikasi pemasaran program pembinaan Remas dengan pendekatan teori AIDA untuk menghadapi remaja muslim. Adapun jenis penelitian yang digunakan adalah penelitian dasar (basic research) yaitu suatu proses pengumpulan dan analisis data/informasi untuk mengembangkan atau memperkaya suatu teori. ${ }^{24}$ Hasil dari studi ini diharapkan dapat menjadi inspirasi dan referensi bagi Remas ataupun lembaga dakwah lain yang ingin melakukan komunikasi pemasaran ke kalangan remaja muslim. Dan diharapkan dapat mengembangkan ilmu dakwah lewat kontekstualisasi penerapan teori komunikasi pemasaran model AIDA pada Remas atau lembaga dakwah ketika menghadapi remaja muslim.

\section{Komunikasi Pemasaran Model AIDA}

Menurut teori Laswell, komunikasi adalah suatu proses yang menjelaskan siapa, mengatakan apa, dengan media apa, kepada siapa, dan apa efek pesan terhadap penerima pesan. ${ }^{25}$ Sedangkan, pemasaran merupakan suatu proses yang terorganisir untuk memperoleh apa yang dibutuhkan dan diinginkan dengan menciptakan, menawarkan, dan mempertukarkan produk yang bernilai dengan pihak lain. ${ }^{26}$ Sehingga, komunikasi pemasaran adalah sarana yang digunakan oleh organisasi untuk menginformasikan, mengingatkan, dan membujuk konsumen secara sadar serta tidak sadar tentang produk yang dijual. ${ }^{27}$

Komunikasi pemasaran model AIDA merupakan proses komunikasi pemasaran dengan memberikan informasi secara bertahap kepada konsumen, yang dimulai dengan tahap kognisi yang berisikan proses Attention (menarik perhatian), tahap afeksi berisikan proses Interest (mempertahankan minat) dan Desire (merangsang kemauan), dan tahap perilaku yang berisikan proses Action (mendorong terjadinya tindakan pembelian). ${ }^{28}$

\footnotetext{
26. Sinta Petri Lestari, "Hubungan Komunikasi Pemasaran dan Promosi dengan Keputusan Memilih Jasa Layanan Kesehatan (Studi Pada Rumah Sakit Islam Lumajang)", Jurnal Interaksi 04, no. 2 (2015): 139-147, doi: https://doi.org/10.14710/interaksi.4.2.139-147

27. Ibid.

28. Johar, Pengaruh AIDA, 5.
} 
Untuk merancang komunikasi pemasaran yang efektif, maka dilakukan proses: 1. Mengidentifikasi audiens sasaran (memahami penerima pesannya seperti apa), 2. Menentukkan tujuan komunikasi (respons apa yang diharapkan), 3. Melakukan proses encoding yang terdiri dari perumusan pesan, pemilihan media, dan mengidentifikasi noise (gangguan) dalam proses pengiriman pesan, 4. Mengumpulkan umpan balik atau feedback setelah proses decoding atau penafsiran pesan oleh penerima. ${ }^{29}$

Adapun operasionalisasi dari model komunikasi pemasaran tersebut, antara lain: Pertama, Mengidentifikasi Audiens Sasaran, yaitu menetapkan siapa sasaran komunikasi pemasaran yang jelas. Dalam tulisan ini telah jelas bahwa yang menjadi audiens sasaran adalah remaja muslim. Remas perlu memahami tentang karakteristik yang memengaruhi remaja muslim dalam melakukan pembelian. Secara umum, beberapa karakteristik yang memengaruhi perilaku pembelian, antara lain: ${ }^{30}$ 1) Faktor budaya yang terdiri dari Budaya, Sub Budaya dan Kelas Sosial; 2) Faktor sosial yang terdiri dari Kelompok Referensi, Keluarga, dan Peran Status; 3) Faktor pribadi, yang terdiri dari Usia Dan Tahap Siklus Hidup, Pekerjaan, Status Ekonomi, Gaya Hidup, serta Kepribadian dan Konsep Diri; 4) Psikologis,

\footnotetext{
29. Nufian S Febriani, Wayan Weda Asmara Dewi, Teori dan Praktis : Riset Komunikasi Pemasaran Terpadu (Malang : Universitas Brawijaya Press, 2018), 4-6.

30. Daniel Teguh Tri Santoso dan Endang Purwanti, "Pengaruh Faktor Budaya, Faktor Sosial, Faktor Pribadi, dan Faktor Psikologis Terhadap Keputusan Pembelian Konsumen dalam Memilih Produk Operator Seluler Indoset-M3 di Kecamatan Pringapus Kab. Semarang", Jurnal Among Makarti 06, no. 12 (2013), 114-118, doi: https://jurnal.stieama.ac.id/index.php/ama/article/vi ew/92

31. Febriani, Teori dan Praktis, 4.
}

terdiri dari Motivasi, Persepsi, Pembelajaran, Kepercayaan dan Sikap. Datadata tersebut yang dijadikan sebagai asumsi untuk perumusan pesan dan pemilihan media yang sesuai dengan remaja muslim.

Kedua, Menentukan tujuan komunikasi pemasaran, yaitu proses dimana pemasar memutuskan respons apa yang mereka cari dari pasar yang sudah ditentukan. ${ }^{31}$ Adapun tahapan kesiapan membeli pasar berbedabeda, $^{32}$ hal tersebut akan mempengaruhi tujuan komunikasi pemasaran.

Berdasarkan teori AIDA, konsumen akan melewati tahapan:

1. Cognitive Stage (tahap kognisi) dengan target attentio, ${ }^{33}$ yaitu proses menyadarkan konsumen terhadap informasi produk. $^{34}$ Pada tahap ini Remas dapat memberikan informasi dasar mengenai produk sebagai upaya untuk membangun kesadaran remaja terhadap Remas. ${ }^{35}$

2. Affective Stage (tahap afeksi) dengan target Interest dan Desire. ${ }^{36}$ Interest fokus menunjukkan sisi keunggulan Remas sehingga remaja muslim merasa suka dan tertarik dengan Remas. ${ }^{37}$ Sementara desire fokus membangun keinginan (minat) remaja terhadap program minat dapat ditumbuhkan dengan menunjukkan seberapa besar manfaat program Remas

\footnotetext{
32. Ujang Sumarwan dan Fandy Tjiptono, Strategi Pemasaran dalam Perspektif Perilaku Konsumen (Bogor : IPB Press, 2019), 483.

33. Sumarwan, Strategi Pemasaran, 472.

34. Lestari, Hubungan Komunikasi Pemasaran, 145.

35. Reza Riesnanda Poetra dan Nevrettia Christantyawati, "Model AIDA : Pola Penggunaan Media Sosial dalam Meningkatkan Kepuasan Penjualan di Toko Online Goldies Hijab", Jurnal Komunikasi Profesional 1, no. 1 (2017), 29, doi: http://dx.doi.org/10.25139/jkp.v1i1.170

36. Sumarwan, Strategi Pemasaran, 472.

37. Poetra, Model AIDA, 29.
} 
dalam menjawab kebutuhan remaja muslim. ${ }^{38}$

3. Behaviour Stage (tahap perilaku) dengan target Action, ${ }^{39}$ yaitu konsumen memutuskan untuk membeli produk. ${ }^{40}$ Pada tahap Remas berupaya meyakinkan remaja muslim agar mengambil keputusan untuk mengikuti program Remas. ${ }^{41}$

Adapun tujuan komunikasi pemasaran ditetapkan berdasarkan kondisi konsumen sudah berada di tahapan yang mana. Jika konsumen telah mencapai tahap afeksi maka pemasar hanya perlu merumuskan komunikasi pemasaran untuk tahap perilaku. Namun jika konsumen bahkan belum mencapai tahap kognisi maka tujuan komunikasi adalah membangun dari tahapan kognisi hingga perilaku. Sehingga untuk menentukan tujuan komunikasi pemasaran Remas maka perlu diketahui remaja muslim saat ini berada pada tahapan kesiapan yang mana.

Ketiga, Melakukan proses encoding yang terdiri dari perumusan pesan, pemilihan media, dan mengidentifikasi noise (gangguan) dalam proses pengiriman pesan. ${ }^{42}$ Remas perlu merancang pesan sesuai dengan tujuan komunikasi pemasaran. Perancangan pesan meliputi tiga hal yaitu strategi pesan, strategi kreatif, dan sumber pesan. ${ }^{43}$ Strategi pesan berbicara tentang apa yang harus dikatakan. Adapun proses perumusannya dengan memilih tema, ide, atau daya tarik apa yang dikaitkan dengan produk atau merek yang akan dikomunikasikan. Pemasar dapat menggunakan daya tarik fungsional dari

38. Ibid.

39. Sumarwan, Strategi Pemasaran, 472.

40. Lestari, Hubungan Komunikasi Pemasaran, 145.

41. Poetra, Model AIDA, 29-30.

42. Teori dan Praktis, 5. produk dengan menyampaikan kualitas produk. Dan juga menggunakan daya tarik emosional dengan cara mengaitkan emosi konsumen seperti bahagia, sedih, sayang, cinta, khawatir, takut, bangsa, atau kecewa, dengan produk. $^{44}$ Strategi kreatif adalah bagaimana pemasar menyampaikan pesan dalam sebuah komunikasi khusus yang dapat dipahami oleh konsumen sasaran. Dalam menyusun strategi kreatif, ada dua pendekatan daya tarik yaitu daya tarik informasi dan daya tarik transformasi. Daya tarik informasi adalah proses komunikasi yang menyampaikan pesan tentang atribut, karakteristik, fitur, atau manfaat fungsional dari produk. Strategi ini cocok untuk konsumen yang rasional dalam mengambil keputusan, yaitu mampu mempertimbangkan manfaat fungsional dari produk dibandingkan dengan beban yang harus ia keluarkan. Sedangkan daya tarik transformasi adalah proses komunikasi yang menyampaikan pesan tentang karakteristik, fitur, atau atribut produk yang tidak berwujud seperti citra dan persepsi produk. Contohnya, pemasar menyampaikan pesan tentang karakter konsumen seperti apa yang menyukai produk. Pendekatan emosional sering digunakan dalam strategi transformasi ini. ${ }^{45}$ Kemudian merumuskan sumber pesan yaitu pihak yang menyampaikan pesan. Pemasar perlu memperhatikan kepribadian, kredibilitas, pengetahuan, dan daya terima konsumen dari seseorang yang akan digunakan sebagai pemberi pesan dari produk yang akan dikomunikasikan. ${ }^{46}$

\footnotetext{
43. Sumarwan, Strategi Pemasaran, 475.

44. Ibid.

45. Ibid., 475-476.

46. Ibid., 477.
} 
Kemudian dalam pemilihan media, Remas harus memilih saluran komunikasi yang tepat yaitu yang dapat dijangkau oleh remaja muslim sebagai audiens sasaran. ${ }^{47}$ Ada 2 jenis saluran komunikasi, yaitu saluran komunikasi pribadi dan saluran komunikasi umum. Yang termasuk sebagai saluran komunikasi pribadi adalah pemasaran langsung dan penjualan personal. Sementara saluran komunikasi umum adalah iklan, promosi penjualan, acara dan pengalaman, dan hubungan masyarakat. ${ }^{48}$

Adapun tiap-tiap saluran komunikasi memiliki karakteristik tersendiri. Iklan, merupakan mode komunikasi yang cocok untuk membangun citra produk dalam jangka panjang. Karakteristik iklan adalah mampu menjangkau wilayah yang luas sehingga banyak konsumen yang dapat dijangkau. ${ }^{49}$ Iklan dapat berbentuk cetak seperti koran, majalah, brosur, leaflet, dll; siaran seperti radio dan televisi; jaringan seperti melalui telepon, televisi kabel, satelit, jaringan tanpa kabel; elektronik seperti internet web, VCD, DVD; ataupun media pajang seperti billboard, papan nama, poster, spanduk, banner. ${ }^{50}$

Promosi penjualan, tepat digunakan untuk menghasilkan respons konsumen dengan cepat. Tapi hanya cocok untuk program jangka pendek saja. Hubungan masyarakat, mode komunikasi untuk membangun citra dengan cara berkomunikasi dengan para pemangku kepentingan sehingga cara pandang positif mereka terhadap produk juga akan memengaruhi cara pandang konsumen terhadap produk. Acara dan pengalaman, mode komunikasi yang cocok

\footnotetext{
47. Ibid.

48. Ibid., 477-479.

49. Ibid., 481.

50. Ibid., 478.
}

jika pemasar ingin membangun hubungan emosional dengan kosumen. Caranya dengan melibatkan konsumen dalam kegiatan acara atau pengalaman, agar konsumen dapat mengalami bagaimana menikmati acara yang dilaksanakan oleh organisasi ataupun berinteraksi dengan pihak organisasi. Pemasaran langsung, mode komunikasi yang bertujuan berkomunikasi langsung dengan konsumen melalui penggunaan media seperti telepon, internet, surat, email, dan media lain. Dengan pemasaran langsung, pemasar dapat berinteraksi langsung dan mendapatkan reaksi segera dari konsumen tentang penawaran produk. Penjualan Pribadi, mode komunikasi yang langsung berinteraksi tatap muka dengan konsumen. Mode ini tepat jika tujuan utama komunikasi adalah untuk meyakinkan kosumen mengenai produk atau memberikan penjelasan terperinci mengenai produk. Dengan mode ini memungkinkan pemasar untuk mengetahui respons konsumen terhadap produk yang ditawarkan. ${ }^{51}$

Remas juga perlu mengidentifikasi noise atau gangguan dalam proses pengiriman pesan. Adanya gangguan dapat menyebabkan terjadinya kesalahan. ${ }^{52}$ Gangguan dapat terjadi karena kesalahan kata atau kalimat yang digunakan sehingga memunculkan makna berbeda yang beragam $^{53}$ ataupun pilihan media yang digunakan, adapun media langsung berpotensi memunculkan gangguan yang lebih kecil dibandingkan media tidak langsung. ${ }^{54}$

\footnotetext{
51. Ibid., $481-482$.

52. Febriani, Teori dan Praktis, 5.

53. Ibid., 6.

54. Ibid.
} 
Keempat, Mengumpulkan umpan balik atau feedback setelah proses decoding atau penafsiran pesan oleh penerima. Pemasar perlu mengevaluasi apakah pesan yang tersampaikan sesuai dengan harapan, artinya mendapatkan respons dan tindakan yang positif atau justru pesan tidak sampai secara efektif. ${ }^{55}$ Untuk mengukur efektifitas pesan dapat dilihat dari tingkat penjualan produk, ${ }^{56}$ atau dalam konteks ini dapat dilihat dari keikutsertaan remaja masjid dalam program Remas.

\section{Remaja Masjid}

Remaja Masjid merupakan organisasi remaja muslim yang melakukan kegiatan Islami dan berada dalam naungan masjid. ${ }^{57}$ Remas memiliki program pembinaan untuk ditawarkan kepada remaja muslim. Program pembinaan Remas diadakan dengan tujuan untuk membentuk pribadi muslim yang takwa dan senantiasa berbakti dan bermanfaat bagi bangsa, negara, dan juga umat. $^{58}$ Sesuai dengan tujuannya, pelaksanaan program pembinaan Remas dilandaskan atas nilai Islami yaitu menjadikan Islam sebagai dasar pembinaan yakni sebagai sumber keyakinan dan sumber nilai di dalam setiap bentuk pembinaan. Dan juga nilai Kebangsaan dimana Pancasila sebagai ideologi negara Indonesia juga harus dijadikan sebagai pedoman dalam berperilaku. ${ }^{59}$

Untuk merealisasikan nilai-nilai yang mendasari (nilai-nilai Islami dan Kebangsaan) dan tujuan dibentuknya, wujud produk yang ditawarkan oleh Remas yaitu

\footnotetext{
55. Ibid., 9.

56 . Ibid.

57. Syakib, Pembinaan Keagamaan, 14-15.

58. Syakib, Pembinaan Keagamaan, 60-61.
}

berupa aktivitas program dan metode pembinaan.

Aktivitas program Remas, antara lain: ${ }^{60}$ 1) Aktivitas ritual dan spiritual, berisikan kegiatan yang berhubungan dengan unsurunsur pelaksanaan peribadatan dan pengembangan rohani, seperti salat rawatib berjamaah, PHBI, pengumpulan dan penyaluran ZIS, tafakur alam, kajian muslimah (keputrian), dll; 2) Aktivitas Intelektual, meliputi kegiatan yang berhubungan dengan peningkatan wawasan keilmuan, seperti kelas diskusi, kajian Islam, bimbingan belajar, bedah buku, bedah film, literasi media, bela negara, dll; 3) Aktivitas Sosial, meliputi kegiatan yang berhubungan dengan aksi dan kepedulian sosial, seperti kerja bakti, penggalangan dana sosial, bakti sosial, penanggulangan bencana, dll; 4) Aktivitas Minat dan Bakat, berisikan kegiatan yang berhubungan dengan potensi remaja dan pemuda masjid, seperti seni budaya islam, olahraga, beladiri, sinematografi, fotografi, pelatihan penulisan, dan minat bakat lainnya. Dari rincian aktivitas program Remas dapat diketahui bahwa Remas tidak hanya fokus pada aspek religius dan spiritual, melainkan juga fokus pada aspek intelektual, sosial dan minat bakat.

Selain itu, beberapa cara Remas dalam melakukan pembinaan kepada para remaja muslim, ${ }^{61}$ antara lain: (a) Melakukan bimbingan agama dan moral secara rasional; (b) Melakukan bimbingan berdiskusi dan bermusyawarah; (c) Menyediakan buku bacaan tentang agama, moral dan ilmu pengetahuan; (d) Memberikan kesempatan

\footnotetext{
59. Ibid.

60. Subdit Kemasjidan, Pedoman Pembinaan Remaja Masjid, 6-7.

61. Ibid., 54.
} 
untuk berperan dan bertanggungjawab sebagai orang dewasa melalui wahana organisasi; (e) Memberikan perlindungan terhadap pengaruh negatif dari lingkungan dan media massa; (f) Membimbing dan mengawasi pergaulan muda mudi; (g) Menyalurkan hobi yang sehat dan bermanfaat; (h) Memberikan kesempatan berolahraga dalam berbagai cabang; (i) Memberikan kesempatan berpiknik. Aspek nilai dan wujud program pembinaan Remas tersebut menjadi produk yang akan ditawarkan kepada remaja muslim.

\section{Komunikasi Pemasaran REMAS dengan Pendekatan Model AIDA}

Perumusan komunikasi pemasaran REMAS dimulai dari proses mengidentifikasi audiens sasaran yang dalam konteks ini adalah remaja muslim. Selanjutnya REMAS perlu menentukkan tujuan komunikasi pemasaran sesuai dengan asumsi remaja muslim terhadap Remas. Kemudian Remas melakukan proses encoding dengan merumuskan pesan, memilih media, dan mengidentifikasi gangguan yang terjadi dalam pengiriman pesan. Pada tahap akhir, Remas juga perlu mengumpulkan umpan balik dari remaja muslim, untuk menguji apakah tujuan komunikasi pemasaran Remas tercapai atau tidak.

\footnotetext{
62. Siti Fatimah, Konsep Pendidikan Remaja Muslim Menurut Abdullah Nashih Ulwan (Tesis Program Pascasarjana, UIN Sumatera Utara, Medan, 2018), 3233.

63. Ibid.

64. Itsna Fitria Rahmah, "Etika Pergaulan Remaja Muslim yang Ramah Ditinjau dari Konsep Peace
}

\section{Mengidentifikasi Audiens Sasaran}

Audiens sasaran Remas adalah remaja muslim. Remaja merupakan masa peralihan antara masa kanak-kanak dan masa dewasa. Remaja dinilai sudah mampu membedakan baik dan buruk, benar dan salah, dan sudah berkewajiban menerima dan memikul beban tanggung jawab. Sedangkan, muslim merupakan substansi dari Islam. Islam membawa sistem nilai-nilai, memberi petunjuk dan peraturan agar manusia taat dan patuh kepada Allah. ${ }^{62}$

Kesimpulannya remaja muslim adalah manusia yang telah mencapai usia beranjak dewasa, mulai berkewajiban menerima dan memikul beban tanggung jawab untuk mengabdikan diri, taat, dan patuh pada petunjuk dan peraturan Allah Swt. ${ }^{63}$

Adapun remaja muslim yang difokuskan adalah remaja muslim Indonesia, karena konteks Remas yang diteliti merupakan Remas di Indonesia.

Adapun data karakteristik remaja muslim yang berpengaruh pada keputusan pembeliannya terhadap suatu produk. Hal itu antara lain: faktor budaya, memiliki pengaruh terhadap kebutuhan remaja muslim akan program pembinaan Remas. Yaitu kebutuhan untuk menghadapi pengaruh budaya yang menyimpang dari nilai-nilai Islami dan Kebangsaan, seperti gaya berpacaran berlebihan, tidak peduli dengan hal sekecil apapun (individual), kurang sopan dengan orang tua. ${ }^{64}$ Dari kebiasaan remaja mengakses internet di smartphonenya, ${ }^{65}$ seperti media sosial Line,

Education, Studi di SMA IslamAl Azhar 14 Semarang", Jurnal Pendidikan Madrasah 1, no. 2 (2016), 246, doi http://ejournal.uin-

suka.ac.id/tarbiyah/index.php/JPM/article/view/1217

65. Yenni Yuniati, Ani Yuningsih, Nurahmawati, "Konsep Diri Remaja dalam Komunikasi Sosial melalui 
Whatsapp, BBM, twitter, facebook, ${ }^{66}$ youtube, dan google, ${ }^{67}$ membuat mereka terpengaruh dengan trend yang ada di internet. ${ }^{68}$ Terlebih di era globalisasi ini banyak budaya baru yang masuk, sementara remaja masih belum bisa memikirkan apakah dampak dari perilakunya membawa kebaikan atau mudharat. ${ }^{69}$

Faktor sosial, akan dibahas dua sub faktor. Yang pertama adalah Kelompok Referensi. Efek dari budaya mengakses internet juga terasa pada pilihan kelompok referensi remaja muslim. Saat ini, remaja muslim menjadikan media sosial sebagai referensinya dalam belajar agama. Mereka merasa lebih mudah belajar melalui internet, misalnya melalui instagram, youtube, dan whatsapp. $^{70}$ Mereka juga senang mendengar ceramah para ustaz medsos, karena mudah untuk diakses dan rata-rata para ustaz medsos menggunakan pola penyampaian yang renyah dan populer. ${ }^{71}$ Yang kedua adalah Keluarga. Dukungan psikologis dari keluarga berperan sangat penting terhadap perkembangan spiritualitas remaja. ${ }^{72} \mathrm{Di}$ dalam unit keluarga, remaja merupakan mitra dakwah orang tua, yakni ayah dan ibu sebagai pelaku dakwah utama dalam keluarga. Orang tua

"Smartphone", Mimbar 31 - Jurnal Sosial dan Pembangunan, no. 2 (2015) : 439 - 450, doi: https://doi.org/10.29313/mimbar.v31i2

66. Ibid.

67. Siti Nurina Hakim dan Aliffatullah Alyu Raj, Dampak Kecanduan Internet (Internet Addiction) Pada Remaja (dipresentasikan dalam Prosiding Temu IImiah X Ikatan Psikologi Perkembangan Indonesia, Hotel Grasia, Semarang, Agustus 2017), 282.

68. Rahmah, Etika Pergaulan Remaja Muslim, 246.

69. Ibid.

70. Muhammad Dachlan, "Media Online dan Pembentukan Pemahaman Keagamaan Siswa di MAN 1 Ambon", Jurnal Mimikri - Jurnal Agama dan Kebudayaan 6, no. 2 (2020), 266, doi: https://blamakassar.ejournal.id/mimikri/article/view/438 memegang peranan penting untuk mengajari, membimbing, dan mengarahkan remaja sehingga mereka memiliki iman dan taqwa kepada Allah Swt, serta memiliki akhlak al-karimah. ${ }^{73}$

Faktor pribadi, ada tiga sub faktor yang dibuka. Yang pertama adalah Usia dan tahap siklus hidup. Ada yang berpendapat bahwa masa remaja berkisar dari usia 12/13 tahun hingga 21/22 tahun. $^{74}$ Namun dalam konteks Remas, kriteria usia remaja muslim ditetapkan sesuai dengan Keputusan Direktur Jenderal Bimbingan Masyarakat Islam Nomor 948 Tahun 2018 tentang Pedoman Pembinaan Remaja dan Pemuda Masjid Bab III Standar SDM yaitu berkisar antara 13 s.d. 30 tahun. $^{75}$

Yang kedua yaitu gaya hidup, diketahui bahwa kebanyakan remaja muslim menjadikan nilai-nilai Islam sebagai nilai yang telah diyakini sejak lama. Mereka beragama Islam karena memang sejak dahulu hidup di lingkungan yang beragama Islam, seperti ayah-ibunya, temannya, dan lingkungan masyarakatnya menganut dan beribadah sesuai dengan ajaran Islam. Akhirnya mereka ikut percaya dan melaksanakan ibadah serta ajaran-ajaran

71. Ibid.

72. Retno Mangestuti dan Rahmat Azis, "Pengembangan Spiritualitas Remaja : Mengapa Remaja Laki-laki Lebih Memerlukan Dukungan Keluarga dalam Pengembangan Spiritualitas", Jurnal Psikoislamika 14, no. 1 (2017) : 31 - 37, doi: https://doi.org/10.18860/psi.v14i1.6500

73. Nuwairah, Peran Keluarga dan Organisasi Remaja Masjid, 5.

74. Sri Wahyuni Mulia dan Azrul Zaid, "Relationship Of Emotional Maturity With Social Interaction Of Student In SMP N 1 Ranah Batahan Pasaman Barat", Jurnal Neo Konseling 01, no. 04 (2019), 1, doi: https://doi.org/10.24036/00158kons2019

75. Subdit Kemasjidan, Pedoman Pembinaan Remaja Masjid, 5. 
agama Islam. ${ }^{76}$ Kemudian pada saat remaja, kebutuhan remaja untuk mengetahui ajaran Islam lebih dalam pun muncul, rasa ingin tahu mereka semakin tinggi, sehingga mereka butuh kegiatan pengajian yang membuat mereka mampu menelaah serta mempelajari Islam sebagai pedoman hidupnya, bukan hanya sekedar diceramahi. ${ }^{77}$

Yang ketiga adalah faktor Kepribadian dan Konsep Diri. Faktor kepribadian dan konsep diri merupakan faktor internal yang menjelaskan kebutuhan remaja muslim akan program pembinaan Remas. Hal itu karena di masa remaja, mereka berada pada masa pencarian jati diri, mulai meneliti sikap hidup dan belajar membentuk kedewasaan. Mereka mulai mempertanyakan tentang standar moral, karena seringkali mereka mengalami kebingungan dan merasakan konflik batin dalam mempertimbangkan keputusan, apakah mengikuti standar moral atau material. Sementara, kehidupan duniawi cenderung lebih dipengaruhi kepentingan akan materi sehingga banyak dari remaja yang cenderung bersikap materialistis. ${ }^{78}$

Dalam hal beragama, mereka butuh untuk mendalami ajaran agama Islam, mengkritisi keyakinan beragama yang diterima dari masa kanak-kanak, agar tertanam keyakinan, keinsyafan paham atau ajaran sehingga terbentuk kesadaran perasaan dan

\footnotetext{
76. Haris Budiman, "Kesadaran Beragama Pada Remaja Islam", Al Tadzkiyyah - Jurnal Pendidikan Islam 6, (2015), 24, https://doi.org/10.24042/atjpi.v6i1.1474

77. Ibid., 17.

78. Ibid.

79. Ibid., 17-18.

80. Ibid., 18

81. Ibid., 22-23.

82. Ibid., 20
}

sikap hidup yang berlandaskan ajaran agama Islam. ${ }^{79}$ Dengan begitu, mereka dapat mencapai kematangan dalam beragama, yaitu mulai menyadari bahwa setiap perilakunya mendapat pengawasan dari Allah, senantiasa mengamalkan ibadah secara ikhlas dan mengambil hikmah dari ibadah tersebut, menjalani problematika hidup dengan bersyukur dan sabar, berupaya untuk memperkokoh ukhuwah islamiyah, serta melakukan amar ma'ruf nahi munkar. ${ }^{80}$ Mereka juga mulai mulai memikirkan tentang dosa dan berusaha mencari proteksi dari dosa. ${ }^{81}$

Secara umum, remaja sudah bisa berpikir menggunakan logika dan rasio, stabilitas mulai timbul dan meningkat, dan citra diri dan sikap pandangan lebih realistis. ${ }^{82}$ Faktor psikologis, berbeda dengan faktor pribadi yang membahas konsistensi reaksi seseorang, faktor psikologis membahas lebih dalam terkait perasaan objek, cara mereka menganalisis dan mengumpulkan informasi, merumuskan pikiran dan pendapat serta mengambil tindakan. ${ }^{83}$ Ada empat sub yang masuk didalamnya. Pertama adalah motivasi. Diketahui bahwa motivasi remaja untuk mengikuti program Remas masih minim. Terbukti dari peminat Remas yang semakin sepi. ${ }^{84}$ Yang kedua adalah faktor Persepsi. Diketahui bahwa persepsi remaja terhadap Remas masih cenderung negatif,

\footnotetext{
83. Andi Muhammad Irwan, "Pengaruh Faktor Psikologis, Pribadi, Sosial dan Budaya Terhadap Keputusan Pembelian Produk Fashion Secara Online (Studi Kasus Pada Konsumen PT. Lazada Indonesia di Kota Makassar), FORECASTING : Jurnal IImiah IImu Manajemen 1, no. 2 (2019) : 167-168, doi: https://stiemmamuju.ejournal.id/FJIIM/article/view/21

${ }^{84}$ Wulandari, Menyiasati yang Muda Agar Giat di Kelompok Remaja Masjid.
} 
yaitu memandang Remas kurang menarik. ${ }^{85}$ Bahkan ada remaja yang tidak tahu bagaimana kiprah remaja masjid bahkan tidak tahu bahwa ada remaja masjid. ${ }^{86}$ Sementara di aspek pembelajaran remaja terhadap Remas masih belum ditemukan datanya karena sampai saat ini mereka belum tertarik ikut Remas sehingga tidak ada pengalaman mengikuti Remas. Terakhir, dalam faktor Kepercayaan dan Sikap diketahui bahwa secara kecenderungan remaja tidak tertarik ikut kegiatan Remas. ${ }^{87}$

\section{Menentukkan Tujuan Komunikasi Pemasaran}

Untuk merumuskan tujuan komunikasi pemasaran perlu untuk mengidentifikasi tahap kesiapan pembeli, ${ }^{88}$ yang terdiri dari tahap kognisi, afeksi, dan perilaku. ${ }^{89}$ Adapun tahapan kesiapan remaja masjid terhadap Remas sehingga mempengaruhi tujuan komunikasi pemasaran Remas, antara lain:

1. Tahap kognisi, diketahui bahwa remaja muslim tidak tahu kiprah Remas ${ }^{90}$, berpersepsi negatif tentang Remas yaitu menganggap Remas tidak menarik karena hanya berisikan agama-agama saja. ${ }^{91}$ Sehingga wajar jika kondisi tersebut menyebabkan remaja muslim tidak terbangun kebutuhannya terhadap Remas. Untuk itu, di tahapan kognisi ada target Attention yaitu menanamkan kesadaran remaja muslim terhadap Remas. ${ }^{92}$ Adapun detail tujuannya adalah: 1) Membangun kebutuhan remaja muslim akan program pembinaan Remas, 2) Memberikan informasi dasar tentang Remas sehingga

\footnotetext{
${ }^{85} \mathrm{NN}$, Ubah Citra Remaja Masjid.

86. Syakib, Pembinaan Keagamaan, 46.

87. Susanto, Keputusan stratejik, 7-8.

88. Febriani, Teori dan Praktis, 4.

89. Sholeh, Proses Hierarchy of Effect, 20.

90. Syakib, Pembinaan Keagamaan, 46.
}

Remas disadari eksistensinya dan dinilai menarik oleh remaja muslim karena ternyata tidak hanya berisikan agamaagama saja.

2. Tahap afeksi merupakan kelanjutan dari tahap kognisi. Setelah remaja muslim menyadari bahwa mereka butuh dan tertarik dengan program pembinaan Remas, maka selanjutnya mereka memerlukan informasi yang lebih dalam tentang Remas. Informasi tersebut disampaikan guna mencapai target di tahap afeksi yaitu interest (membuat remaja muslim suka dengan program pembinaan Remas) dan desire (membuat remaja muslim berminat dengan program pembinaan Remas). ${ }^{93}$ Adapun detail tujuan tahap afeksi, antara lain: 1) Interest : remaja muslim tahu dan suka dengan aktivitas program dan metode pembinaan Remas, 2) desire: remaja muslim yakin program pembinaan Remas dapat menjawab kebutuhannya untuk mendalami ajaran Islam, mengetahui standar moral, mencari jati diri menuju kedewasaan dapat terjawab dengan mengikuti Remas.

3. Tahap perilaku yang berisikan Action merupakan tahap akhir setelah kognisi dan afeksi sudah terbangun. Tahap perilaku bertujuan untuk mendorong remaja muslim agar memutuskan untuk mengikuti program pembinaan Remas. ${ }^{94}$

\section{Proses Encoding}

Di dalam proses encoding, Remas perlu untuk merumuskan pesan, memilih media, dan mengidentifikasi gangguan yang

\footnotetext{
91. NN, Ubah Citra Remaja Masjid.

92. Lestari, Hubungan Komunikasi Pemasaran, 145.

93. Ibid.

94. Ibid.
} 
mungkin datang saat proses pengiriman pesan. ${ }^{95}$ Dalam teori komunikasi pemasaran, proses encoding disesuaikan dengan tujuan komunikasi pemasaran. ${ }^{96}$ Sehingga dalam konteks Remas proses encoding dimulai dari tahap kognisi, tahap afeksi, dan tahap perilaku.

\section{Tahap Kognisi}

Berisikan target attention dengan detail tujuan yaitu menyadarkan remaja muslim: 1 ) bahwa mereka membutuhkan program pembinaan Remas, 2) bahwa Remas ternyata menarik, kegiatannya tidak hanya agama-agama saja. ${ }^{97}$

\section{Pesan Kognisi}

Tujuan kognisi pertama: menyadarkan remaja muslim bahwa mereka membutuhkan program pembinaan Remas. Adapun pesan yang dapat disampaikan adalah: 1) Menyampaikan permasalahanpermasalahan yang dialami oleh remaja, seperti sedang mencari jati diri dan belajar menuju kedewasaan karena sudah bukan lagi anak-anak; ${ }^{98}$ ingin mengetahui standar moral dan sikap hidup yang benar karena selama ini seringkali bingung mengambil keputusan; ${ }^{99}$ butuh untuk mendalami ajaran agama Islam dan mengkritisi pemahaman Islam yang telah didapati sejak kecil,, ${ }^{100}$ contohnya, mulai penasaran dengan pendasaran dari suatu ibadah seperti kenapa harus salat, dll. Permasalahan yang dialami oleh remaja disampaikan agar mereka menghayati dan menyadari bahwa memang benar mereka mengalami masalahmasalah tersebut dan membutuhkan solusi. 2) Setelah masalah remaja telah

\footnotetext{
95. Febriani, Teori dan Praktis, 5.

96. Ibid.

97. Lestari, Hubungan Komunikasi Pemasaran, 145.

98. Budiman, Kesadaran Beragama, 17.
}

disampaikan kemudian disampaikan terkait dengan tujuan dan nilai yang ditawarkan oleh program pembinaan Remas yaitu membentuk pribadi muslim yang takwa dan senantiasa berbakti dan bermanfaat bagi bangsa, negara, dan juga umat. ${ }^{101}$ Nilai kualitas tersebut menjadi citra program yang ditawarkan oleh Remas. Bahwa program pembinaan Remas hendak membentuk cerminan pribadi seperti itu.

Dengan rumusan pesan tersebut, maka daya tarik emosional dipilih sebagai strategi pesannya. Pertimbangannya karena pesan yang disampaikan perlu dikaitkan dengan emosi yaitu emosi khawatir ketika menyampaikan masalah yang dialami oleh remaja. Dan juga emosi senang dan puas ketika menyampaikan solusi atas masalah yang dialami oleh remaja. Pada strategi pesan, penggambaran emosi dapat diwujudkan dengan pemilihan kata. Contohnya, untuk menggambarkan emosi khawatir dapat menggunakan kata yang mengandung rasa negatif dan kata majas, misalnya "hidup kian hari kian membingungkan (kata bermuatan emosi negatif), berjuta pilihan seolah menyerbu dan memaksaku untuk memilih (majas hiperbola)". Untuk emosi senang dan puas tentu dipilih kata yang mengandung emosi positif dan majas, misalnya "selalu ada cahaya bagi yang mencarinya (majas personifikasi), kini ku temukan jawaban (kata bermuatan positif) atas segala kerisauanku.

Kemudian daya tarik transformasi dipilih sebagai strategi kreatifnya.

\footnotetext{
99. Ibid.

100. Ibid, 17-18.

101. Syakib, Pembinaan Keagamaan, 60-61.
} 
Pertimbangannya karena pesan yang disampaikan tidak berwujud yaitu berupa persepsi dan citra. Ketika menyampaikan permasalahan-permasalahan remaja, Remas sedang menanamkan persepsi kepada remaja bahwa masalah tersebut pasti akan atau mungkin sedang mereka alami. Dan ketika sedang menawarkan tujuan dan nilai dari pembinaan Remas, itu merupakan proses menawarkan citra program. Strategi kreatif berfokus pada cara penyampaian Remas kepada remaja muslim. ${ }^{102}$ Adapun untuk menyampaikan persepsi kekhawatiran akan masalah yang dihadapi oleh remaja muslim, maka cara penyampaian yang dapat digunakan yaitu dibuat naratif (bercerita) secara detail, dengan jeda yang lambat agar tertangkap setiap detail penggambaran masalahnya, dan intonasi datar seolah menggambarkan kebimbangan dan kekhawatiran. Kemudian untuk menawarkan citra program pembinaan Remas maka, cara penyampaiannya adalah dengan intonasi yang bersemangat, dengan jeda yang cepat agar terasa semangatnya. Kemudian perlu juga dirumuskan terkait dengan bentuk dan struktur pesannya. Untuk pesan attention tujuan pertama ini cocok disampaikan dalam bentuk video, gambar, lisan, ataupun tulisan, dengan catatan dapat menggambarkan emosi yang hendak dibangun. Hal itu penting karena strategi pesan yang dirumuskan adalah daya tarik emosional. Kemudian, untuk struktur penyampaian pesannya yaitu menyampaikan masalah yang dialami remaja muslim terlebih dahulu kemudian baru menyampaikan tentang solusi nilai program pembinaan Remas.
Sumber pesan yang cocok untuk menyampaikan pesan adalah seseorang yang dipandang memiliki masalah yang sama yaitu seusia dengan remaja dan sedang mengalami permasalahan juga, hal ini supaya timbul kedekatan psikologis sehingga pesan lebih mudah diterima. Orang yang menyampaikan pesan pun harus dipandang punya pengetahuan yang lebih dan terkenal solutif (mampu membantu menyelesaikan masalah remaja), hal itu karena pesan yang hendak disampaikan tidak hanya tentang masalah namun juga solusi dari masalah remaja yang galau dengan hidupnya.

Tujuan kognisi kedua: bahwa Remas ternyata menarik, kegiatannya tidak hanya agama-agama saja. ${ }^{103}$ Untuk itu pesan yang dapat disampaikan, yaitu gambaran kegiatan di Remas ${ }^{104}$ yang tidak hanya berisikan aktivitas ritual dan spiritual saja melainkan ada aktivitas intelektual, sosial, dan minat bakat juga. Karena sifatnya hanya menyampaikan gambaran dari program Remas sehingga sisi kualitas yang ditonjolkan kepada remaja muslim di tahap awal ini tidak harus sampai detail. Cukup dikenalkan tentang bidang aktivitas dalam pembinaan Remas dan ada aktivitas apa saja dalam setiap bidang tersebut.

Strategi pesan yang digunakan adalah daya tarik fungsional karena pesan yang hendak disampaikan berisikan kualitas produk. Adapun kata yang digunakan harus yang jelas dan dapat dimengerti oleh remaja muslim, bukan ambigu atau tidak dikenal oleh remaja muslim. Contohnya, menggunakan bahasa gaul remaja, tidak

104. Subdit Kemasjidan, Pedoman Pembinaan Remaja Masjid, 6-7.

102 Sumarwan, Strategi Pemasaran, 475-476.

103. Lestari, Hubungan Komunikasi Pemasaran, 145 
menggunakan bahasa asing yang membuat remaja bingung.

Untuk rumusan dan strategi pesan tersebut, maka strategi kreatifnya menggunakan daya tarik informatif. Pertimbangannya karena pesan yang hendak disampaikan berupa kualitas fungsional dari produk sehingga dengan penyampaian informatif saja sudah cukup. Adapun cara penyampaian pesannya dengan deskriptif, jeda yang normal, intonasi yang jelas. Untuk menyampaikan pesan gambaran aktivitas program pembinaan Remas bisa dalam bentuk video, gambar, tulisan, dan lisan.

Sumber pesan yang cocok untuk menyampaikan pesan adalah seseorang yang dipandang memiliki pengetahuan tentang Remas karena informasi yang disampaikan berhubungan dengan kualitas program pembinaan Remas.

\section{Media dan Gangguan dalam Pengiriman Pesan Kognisi}

Dengan asumsi remaja muslim yang belum terbangun kebutuhannya terhadap Remas dan belum ada ketertarikan pada Remas, maka dapat disimpulkan bahwa masalah komunikasi pemasaran Remas di kalangan remaja cukup mendasar. Dengan kondisi sasaran yang demikian, Remas perlu mengupayakan dengan kuat agar tujuan kognisi dapat sukses. Untuk itu, dipilihlah saluran komunikasi umum dan pribadi untuk menyampaikan pesan kognisi. Tujuannya agar pesan tidak hanya menyebar secara luas saja melainkan juga diterima dengan baik oleh masing-masing personal sasaran.

105. Sumarwan, Strategi Pemasaran, 490

106. Rahmah, Etika Pergaulan Remaja, 246.
Adapun media yang digunakan, adalah: 1) Iklan internet melalui media sosial, digunakan karena jangkauannya luas, ${ }^{105}$ cocok untuk konteks Remas yang perlu menarik perhatian sebanyak-banyaknya dari remaja agar semakin banyak yang tertarik mendalami tentang Remas. Dengan menyesuaikan asumsi remaja yang suka mengakses internet dan medsos, ${ }^{106}$ maka bentuk iklan yang sesuai adalah elektronik yaitu iklan melalui internet web. Contohnya melalui medsos instagram, twitter, facebook, dll. Jika memasang iklan di internet, keuntungannya adalah secara biaya lebih rendah, media populer di kalangan remaja, interaktif, jangkauannya luas, dan dapat memuat informasi yang lengkap. Namun gangguannya adalah tidak semua remaja akan mengakses alamat medsos Remas dan secara waktu cenderung singkat karena media sosial mudah sekali terupdate dengan informasi yang baru, ${ }^{107}$ akhirnya pemasar harus rajin mengupload pesan kognisi dengan beragam variasi agar pesan tidak tenggelam dengan pesan lainnya. Bisa berbentuk gambar komik, video singkat, gambar quotes, atau lain-lain sehingga media sosial terus terupdate dengan informasi pesan kognisi. 2) Iklan bentuk media pajang seperti spanduk, poster ataupun banner yang dipasang ditempat-tempat strategis yang sering dikunjungi oleh remaja, misalnya di depan gang akses utama wilayah setempat, didepan masjid. Media pajang dapat menjadi alat bantu untuk menstimulus remaja agar menyadari dan mau untuk berkunjung ke alamat web Remas. Kelebihan menggunakan media pajang adalah pesan dapat dijangkau oleh remaja dan kemungkinan remaja akan terpapar

\footnotetext{
107. Sumarwan, Strategi Pemasaran, 490.
} 
berulang kali oleh pesan tersebut, secara biaya pun masih tergolong murah. Namun gangguan terjadi jika pilihan produk terlalu banyak, ada kesamaan produk, atau informasi yang ambigu, ${ }^{108}$ akhirnya pesan tidak tertangkap oleh remaja. Untuk mengatasi hal tersebut maka perlu membuat desain kata dan tampilan yang menarik dan jelas sehingga remaja termotivasi untuk melihat iklan yang dipajang. Kemudian, perlu diperhatikan juga ukurannya yaitu jangan terlalu kecil tapi terlihat cukup untuk dipandang. 3) Penjualan pribadi, media ini juga dapat digunakan untuk menyampaikan pesan kognisi. Terlebih untuk remaja yang tergolong jarang mengakses media dan akan lebih suka jika dijelaskan secara langsung maka media ini cocok. Adapun teknisnya bisa dengan mengajak makan bersama, melakukan hobi bersama, atau ide lain yang membuat pemasar dapat berinteraksi langsung dengan remaja. Dengan penjualan langsung akan lebih mudah mengidentifikasi respons remaja sehingga pemasar juga lebih mudah mengarahkan remaja untuk lebih mendalami tentang Remas. Ketika melakukan komunikasi dengan saluran pribadi maka gangguan dapat diminimalisir karena pemasar dapat langsung merespons jika ada respons yang kurang sesuai dari sasaran. ${ }^{109}$ 4) Pemasaran langsung, media ini dapat digunakan juga untuk menyampaikan pesan kognisi terutama kepada remaja yang memang sulit ditemui secara langsung dan kurang tertarik untuk mendalami langsung ke website. Remas dapat menggunakan

108. Jati Waskito dan Wahyono, "Upaya Mengurangi Skeptisisme Iklan Hijau Dalam Meningkatkan Perilaku Pembelian Produk Hijau", BENEFIT - Jurnal Manajemen dan Bisnis 1, no. 2 (2016), 110, doi: 10.23917/benefit.v1i2.3254

109. Yustina Chrismardani, "Komunikasi Pemasaran Terpadu : Implementasi Untuk UMKM", Jurnal NeO-Bis media yang sering dipakai remaja juga seperti Line, whatsapp, ${ }^{110}$ telegram, dll. Dengan menggunakan media pemasaran langsung juga akan memudahkan pemasar untuk mengetahui respons personal dari remaja. Dan memudahkan juga untuk mengarahkan agar remaja mendalami Remas. Adapun secara gangguan lebih minim karena menggunakan saluran pribadi. ${ }^{111}$ 5) Iklan berbentuk cetak seperti leaflet. Secara bentuk lebih ringkas. Leaflet dibuat untuk menjelaskan secara singkat tentang Remas dan mengajak remaja agar mendalami tentang Remas. Kelebihannya adalah lebih fleksibel karena remaja dapat membaca dimanapun dan kapanpun, serta pesan dapat dirancang sesuai asumsi remaja. Namun secara kelemahannya kemungkinan akan mendapatkan perhatian yang rendah dari remaja. ${ }^{112}$ Kelemahan ini tentu akan memunculkan gangguan karena akhirnya pesan tidak tertangkap oleh remaja. Untuk mengantisipasi hal itu maka tidak bisa hanya diberikan leaflet melainkan perlu ada tindakan aktif dari pemasar. Jadi media leaflet perlu didampingi dengan media aktif seperti pemasaran langsung atau penjualan pribadi.

\section{Tahap Afeksi}

Berisikan target interest dan desire dengan detail tujuan yaitu: 1) interest: remaja muslim tahu dan suka dengan aktivitas program dan metode pembinaan Remas, 2) desire: remaja muslim yakin program pembinaan Remas dapat menjawab kebutuhannya untuk mendalami ajaran

\footnotetext{
8, no. 2 (2014), 187, doi: https://doi.org/10.21107/nbs.v8i2.472

110. Yuniati, Konsep Diri Remaja, 439 - 450.

111. Chrismardani, Komunikasi Pemasaran Terpadu, 187.

112 Sumarwan, Strategi Pemasaran, 490.
} 
Islam, mengetahui standar moral, mencari jati diri menuju kedewasaan dapat terjawab dengan mengikuti Remas.

\section{Pesan Afektif}

Tujuan interest: remaja muslim tahu dan suka dengan aktivitas program dan metode pembinaan Remas. Maka rumusan pesannya, antara lain: 1) Menjelaskan tentang tujuan dari aktivitas program pembinaan Remas, yaitu tujuan adanya bidang ritual-spiritual, sosial, intelektual dan minat bakat. Disimpulkan kembali secara umum kualitas remaja muslim yang hendak dibangun dengan diberikannya semua bidang program pembinaan tersebut, yaitu dikembalikan kepada tujuan Remas; ${ }^{113}$ 2) Menjelaskan detail informasi setiap aktivitas pada tiap bidang pembinaan Remas ${ }^{114}$. Misalnya, di bidang intelektual ada aktivitas kajian islam, maka perlu dijelaskan deskripsi umum, tujuan, dan manfaat yang diterima oleh remaja muslim dari kegiatan tersebut; 3) Memaparkan tentang metode pembinaan yang digunakan oleh Remas yaitu dengan cara rasional, mengajak remaja muslim untuk diskusi, musyawarah, mengambil peran, dan aktif dalam kegiatan yang diadakan.

Karena berisikan tentang kualitas program Remas maka strategi pesan yang digunakan adalah daya tarik fungsional. Kualitas program pembinaan Remas perlu digambarkan dengan detail, jelas, dan menggunakan bahasa yang dipahami oleh remaja muslim. Agar remaja muslim menyukai program pembinaan Remas maka coba disampaikan program yang paling unggul atau banyak peminatnya terlebih dahulu. Tentu ini membutuhkan analisis

\footnotetext{
113 Syakib, Pembinaan Keagamaan, 60-61.
}

lebih lanjut tergantung dari asumsi spesifik remaja muslim yang dihadapi.

Untuk strategi kreatifnya menggunakan daya tarik informatif karena cara Remas hendak memaparkan program dan keunggulan dari programnya tentu cara penyampaian yang cocok adalah informatif. Pesan disampaikan dengan deskriptif, intonasi yang jelas, jeda yang normal, serta bentuk pesan bisa lewat video, gambar, ataupun tulisan. Untuk lisan bisa tapi mungkin sifatnya hanya melengkapi bentuk pesan yang selainnya karena jika disampaikan detail program secara lisan akan sulit, terlalu banyak pesan yang harus disampaikan oleh komunikator dan terlalu banyak pesan yang perlu dicerna komunikan.

Tujuan desire: remaja muslim yakin program pembinaan Remas dapat menjawab kebutuhannya untuk mendalami ajaran Islam, mengetahui standar moral, mencari jati diri menuju kedewasaan dapat terjawab dengan mengikuti Remas. Adapun rumusan pesan yang dapat disampaikan, yaitu : 1) Analisis kesesuaian antara program yang dijalankan oleh Remas dengan kebutuhan remaja muslim. Dari manfaat yang telah dipaparkan dari setiap aktivitas program maka perlu dihubungkan dengan kebutuhan remaja muslim. Contohnya, aktivitas kajian Islam, kajian keputrian, dll dapat menjawab kebutuhan remaja muslim untuk mendalami ajaran islam; 2) Testimoni dari kegiatan pembinaan Remas yang membentuk pribadi yang positif dan berkualitas sesuai nilai Islam dan Kebangsaan.

\footnotetext{
114 Subdit Kemasjidan, Pedoman Pembinaan Remaja Masjid, 6-7.
} 
Strategi pesan yang digunakan untuk memaparkan analisis kesesuaian antara program Remas dan remaja muslim adalah daya tarik fungsional. Agar dapat meyakinkan remaja muslim maka perlu memilih kata yang jelas dan yakin, jangan menggunakan kata "mungkin, bisa jadi, dll" yang menggambarkan keraguan karena tujuan pesan untuk meyakinkan. Selain itu strategi pesan dengan daya tarik emosional juga dibutuhkan ketika menyampaikan testimoni mengikuti program pembinaan Remas. Adapun emosi yang dikaitkan adalah rasa senang dan bersyukur dengan program pembinaan Remas. Kata yang digunakan sebaiknya mengandung emosi positif seperti "bersyukur mengenal REMAS karena masalahku dapat terjawab".

Strategi kreatif yang digunakan ada daya tarik informatif untuk memaparkan analisis kesesuaian antara program Remas dengan kebutuhan remaja muslim. Adapun cara penyampaian pesannya adalah dengan analisa deskriptif, intonasi yang jelas, jeda yang normal agar pesan tertangkap jelas. Bentuk pesan yang digunakan pun sebaiknya lisan atau bentuk video karena sifatnya adalah pemaparan analisis, jika dalam bentuk tulisan atau gambar khawatir ada kesalahpahaman dalam menginterpretasi pesan. Selain itu, strategi kreatif transformatif pun dibutuhkan untuk menyampaikan pesan yang emosional berupa testimoni dari program pembinaan Remas. Pesan perlu disampaikan dengan ekspresi senang, jeda yang normal hingga cepat untuk menunjukkan semangat dan rasa senang, intonasi jelas. Pesan dapat disampaikan dengan bentuk lisan, video, ataupun gambar dan tulisan. Namun, akan lebih bagus jika dalam bentuk lisan dan video supaya terlihat ekspresinya.

Adapun, sumber pesan yang cocok untuk menyampaikan pesan afeksi interest dan desire adalah seseorang yang dipandang mengetahui secara mendalam tentang Remas. Dikenal sebagai orang yang jujur dan dapat mempertanggungjawabkan apa yang disampaikan.

\section{Media dan Gangguan Penyampaian Pesan Afeksi}

Media afeksi berperan untuk menyampaikan pesan afeksi baik pesan interest maupun desire. Adapun rumusan medianya, antara lain: 1) Iklan internet melalui youtube, instagram, twitter, dll. Cara ini menyesuaikan asumsi remaja yang memang suka mengakses internet. Dengan pengemasan video dan gambar barangkali akan lebih menarik bagi remaja. Secara teknis gambarannya adalah youtube menampilkan profil Remas detail sampai ke pendetailan program dan manfaatnya. Kemudian instagram, twitter, facebook, ataupun media sosial lain ikut mempromosikan video youtube tersebut agar remaja mau melihat video lengkapnya di youtube. Selain itu pemasar juga dapat menggunakan instagram, facebook, twitter untuk ikut menampilkan tiap-tiap program dalam bentuk gambar dan penjelasan ataupun video singkat. Secara umum dengan iklan lewat internet memang lebih murah, variatif caranya, dan mudah diakses berkalikali. Namun, memang kekurangannya adalah tidak dapat mengontrol kemauan remaja untuk mengakses web yang kita miliki. Maka ini menjadi gangguan dalam pengiriman pesan. ${ }^{115}$ Sehingga, pemasar perlu untuk menstimulus personal remaja

115. Sumarwan, Strategi Pemasaran, 490. 
secara aktif agar sasaran mau membuka iklan internet yang telah dibuat (menggunakan saluran pribadi). Misalnya, dengan memfollow akun medsos mereka, kemudian mengirimkan pesan ke personal message-nya. Selain itu, dalam pengemasan pesan pun perlu diperhatikan agar terlihat menarik sehingga mereka terdorong untuk membuka. 2) Iklan cetak berbentuk brosur juga dapat digunakan untuk menyampaikan pesan afeksi yang cenderung padat. Brosur dapat menjadi profile program Remas juga dalam bentuk cetak. Kelebihannya lebih praktis karena bisa dimiliki dan dilihat berkali-kali oleh remaja, namun secara biaya tentu lebih mahal jika dibandingkan dengan menyebar profile lewat online. Selain itu juga ada kemungkinan gangguan dimana brosur kurang mendapatkan perhatian dari remaja. ${ }^{116}$ Akhirnya, pesan tidak tertangkap oleh remaja. Maka, untuk mengantisipasinya bisa dengan melakukan tindakan lanjut secara aktif melalui saluran komunikasi pribadi seperti pemasaran langsung atau penjualan pribadi. Tujuannya untuk memastikan remaja memahami isi dalam brosur. 3) Pemasaran langsung untuk menjelaskan program Remas secara personal ke tiap remaja melalui media seperti Line, whatsapp, dll. Keuntungannya adalah mendapatkan respons langsung dari remaja sehingga dapat mengetahui tingkat ketertarikan remaja terhadap Remas. Ini juga meminimalisir terjadinya gangguan. Namun, memang diperlukan kefokusan SDM untuk melayani pemasaran langsung dengan remaja karena pemasar perlu menjelaskan program Remas satu per satu ke tiap personal. Meskipun bisa juga dibantu dengan share video profile Remas namun tetap saja pelayanannya personal. 5)

116. Ibid.
Penjualan pribadi, digunakan untuk menjelaskan manfaat program Remas secara tatap muka dengan remaja. Untuk itu akan lebih mudah mendapatkan respons dari remaja dan memberikan jawaban yang sesuai dengan pertanyaannya. Dan akhirnya meminimalisir juga adanya gangguan dalam penyampaian pesan.

\section{Tahap Perilaku}

Berisikan target action, yaitu: mendorong remaja muslim agar memutuskan untuk mengikuti program pembinaan Remas.

\section{Pesan Perilaku}

Untuk mencapai tujuan tahap perilaku, maka rumusan pesannya adalah: 1) Ajakan untuk mengikuti program Remas agar bisa mendapatkan manfaat-manfaat positif ketika ikut kegiatan Remas, 2) Ajakan untuk menjadi remaja muslim yang memiliki karakter sesuai dengan nilai Islam dan nilai Kebangsaan. ${ }^{117}$ Remas dapat melekatkan image bahwa remaja yang mau mengikuti Remas adalah remaja yang produktif, mengejar manfaat, cinta agama dan negaranya.

Strategi pesan yang sesuai untuk pesan perilaku adalah menggunakan daya tarik emosional. Karena isi pesan perilaku adalah ajakan-ajakan positif untuk ikut Remas. Untuk itu perlu dipilih kata yang bermuatan emosi positif, mengandung semangat, seperti kata "ayo semarakkan remaja masjid".

Strategi kreatif yang cocok untuk menyampaikan pesan perilaku adalah menggunakan daya tarik transformasi. Cara penyampaiannya dengan menunjukkan ekspresi yang senang dan semangat, jeda

117. Syakib, Pembinaan Keagamaan, 60-61. 
pengucapan yang normal hingga cepat untuk menunjukan adanya semangat, dan intonasi yang jelas. Pesan dapat disampaikan dalam bentuk lisan, video, ataupun gambar dan tulisan.

Sumber pesan yang cocok untuk menyampaikan pesan action adalah orang yang dipercaya memiliki kualitas moral dan pengetahuan yang lebih dibandingkan remaja muslim lain, pilihan sikap dia menjadi panutan karena senantiasa solutif terutama dalam pilihan kegiatan bermanfaat. Subjek yang demikian mengindikasikan dia telah dipercaya oleh remaja lain sebagai referensi dalam bersikap.

\section{Media dan Gangguan Penyampaian Pesan Perilaku}

Adalah media yang digunakan untuk menyampaikan pesan perilaku. Adapun media yang dapat digunakan, antara lain: 1 ) Iklan cetak berbentuk leaflet yang berisikan ajakan untuk ikut Remas. Namun gangguannya jika hanya pakai leaflet adalah kurang diperhatikan oleh remaja, ${ }^{118}$ sehingga perlu didampingi juga dengan penggunaan saluran komunikasi pribadi seperti, penjualan personal atau pemasaran langsung. 2) Iklan internet lewat media sosial Remas untuk mengajak remaja untuk mengikuti Remas. Namun, memang kekurangannya adalah tidak dapat mengontrol kemauan remaja untuk mengakses web yang kita miliki. Maka, ini menjadi gangguan dalam pengiriman pesan. Sehingga, pemasar perlu untuk menstimulus personal remaja secara aktif agar sasaran mau membuka iklan internet yang telah

118. Sumarwan, Strategi Pemasaran, 490.

119. Ibid., 492.

120. Ibid.

121. Febriani, Teori dan Praktis, 6. dibuat (menggunakan saluran pribadi). Misalnya, dengan memfollow akun medsos mereka, kemudian mengirimkan pesan ke personal message-nya. Selain itu, dalam pengemasan pesan pun perlu diperhatikan agar terlihat menarik sehingga mendorong untuk dibuka. 3) Pemasaran langsung dimana pemasar langsung menawarkan kepada remaja lewat media yang selama ini sudah terjalin. Melalui media personal justru akan memudahkan pemasar untuk mengatasi hambatan-hambatan personal untuk mengikuti Remas. 4) Penjualan pribadi dimana pemasar langsung menawarkan kepada remaja secara tatap muka. Sekaligus pada momen ini juga bisa di buka dialog personal yang barangkali menghambat remaja untuk ikut Remas. 5) Promosi Penjualan jenis gift with purchase ${ }^{119}$ dimana Remas berupaya mengajak remaja agar mau ikut program Remas dengan menjanjikan diberikannya hadiah jika datang di acara perdana Remas. Contohnya, diberikan pin, buku notes, atau hadiah lain yang menarik tapi tetap menggambarkan nilai yang ditawarkan oleh Remas yaitu remaja berkarakter sesuai dengan nilai Islam dan nilai Kebangsaan. ${ }^{120}$

\section{Mengumpulkan Umpan Balik}

Setelah proses encoding, maka Remas perlu mengumpulkan respons dari remaja muslim terhadap pesan yang disampaikan (umpan balik). ${ }^{121}$ Adapun, umpan balik bisa berupa tindakan remaja muslim sesuai dengan tujuan yang hendak dicapai atau berasal dari pertanyaan atas kebingungan mereka dalam memahami pesan. ${ }^{122}$ Jika komunikasi

\footnotetext{
122. Popon Srisusilawati, "Kajian Komunikasi Pemasaran Terpadu dalam Mendorong Keputusan Pembelian Jasa Perbankan", Jurnal Ekonomi dan Keuangan Syariah 01, $\begin{array}{lllll}\text { no. } & 01 & \text { (2017) }\end{array}$ https://doi.org/10.29313/amwaluna.v1i1.1993
} 
pemasaran dilakukan lewat saluran pribadi baik seperti penjualan pribadi maka bisa langsung mendapatkan umpan balik dari konsumen. ${ }^{123}$

Adapun dalam setiap tahapan komunikasi pemasaran yaitu tahap kognisi, afeksi, dan perilaku, Remas selalu menggunakan saluran pribadi baik penjualan pribadi atau pemasaran langsung. Maka jika ingin mendapatkan umpan balik langsung dapat memanfaatkan kedua media tersebut. Adapun data yang diperlukan tentu disesuaikan dengan tujuan dari setiap tahapan, yaitu:

1. Tahap kognisi, sesuai dengan tujuan kognisi maka untuk feedback dapat diidentifikasi dari: 1) Aspek komunikasi dengan mempertanyakan secara lisan terkait tanggapan atas pesan: apakah mengalami masalah yang dipaparkan?, apakah merasa membutuhkan pembinaan Remas?, apakah masih menilai Remas tidak menarik?; 2) Aspek sikap dapat diidentifikasi dari antusias mereka untuk mendalami Remas.

2. Tahap afeksi, dihubungkan kembali dengan tujuan afeksi maka feedback dapat diidentifikasi dari : 1) Aspek komunikasi dengan menanyakan apakah ada yang ingin ditanyakan terkait dengan program dan metode pembinaan Remas, atau ingin mengkritisi kembali terkait dengan manfaat Remas bagi remaja muslim, atau dapat terlihat juga dari komentar mereka terhadap penjelasan program dan manfaat pembinaan Remas apakah positif atau negatif responnya; 2) Aspek sikap dapat diidentifikasi dari antusias mereka untuk mendalami program, manfaatnya serta metode pembinaan Remas.

123. Chrismardani, Komunikasi Pemasaran Terpadu, 187.
3. Tahap perilaku, sesuai dengan tujuan perilaku maka feedback dapaaat diidentifikasi dari: 1) Aspek komunikasi seperti menyatakan keminatan untuk ikut program pembinaan Remas, berupaya menanyakan ketika ada kendala teknis untuk mengikuti program pembinaan Remas; 2) Aspek sikap yaitu mendaftarkan diri untuk ikut serta dalam program pembinaan Remas, dan lebih bagus lagi ketika mereka juga ikut mengajak teman remaja lain untuk ikut program Remas juga.

\section{Kesimpulan}

Remas di Indonesia kini sudah semakin meredup. Hanya beberapa Remas saja yang selalu maju dan berkembang sementara yang selainnya belum. Dewan Masjid Indonesia pun menilai bahwa regenerasi remaja masjid sangat dibutuhkan di Indonesia. Untuk itu, studi ini dibuat dengan maksud mengatasi salah satu penyebab sepinya Remas. Adapun ditemukan salah satu sebabnya karena remaja muslim ada yang belum mengenal Remas dan ada juga yang memiliki anggapan yang keliru tentang Remas yaitu menilai Remas tidak menarik, hanya berisikan kegiatan agama-agama saja. Untuk mengatasi persoalan tersebut maka dibuatlah rumusan komunikasi pemasaran untuk program pembinaan Remas dengan menggunakan pendekatan teori komunikasi pemasaran model AIDA. Dari asumsi remaja muslim diketahui kondisi bahwa mereka belum terbangun kebutuhan untuk mengikuti program pembinaan Remas, sehingga wajar jika akhirnya mereka tidak tertarik, tidak ingin mendalami, dan tentu tidak tergerak untuk mengikuti program 
pembinaan Remas. Padahal secara kondisi mereka membutuhkan program pembinaan Remas karena kondisi mereka yang sedang dalam proses pencarian jati diri, sedang meneliti sikap hidup dan standar moral yang benar, bahkan ada keinginan untuk mendalami ajaran agama Islam yang selama ini telah diyakini.

Dalam teori komunikasi pemasaran model AIDA disampaikan bahwa ada tahapan respons yang akan dilalui oleh remaja muslim, dimulai dari kognisi, afeksi, terakhir perilaku. Masing-masing tahapan memiliki target, di tahap kognisi ada target attention pun yaitu menyadarkan mereka akan kebutuhan terhadap program pembinaan Remas dan kemudian diberikan penjelasan bahwa Remas tidak hanya berisikan kegiatan agama saja. Selanjutnya, di tahap afeksi juga dibangun informasi lebih mendalam tentang program pembinan Remas terutama manfaat program dan kesesuaiannya dengan kebutuhan remaja muslim, tujuannya untuk mencapai target interest (membuat remaja muslim suka dengan program pembinaan Remas) dan target desire (meyakinkan remaja muslim akan program pembinaan Remas). Kemudian, barulah di tahap perilaku ada target action yaitu membuat remaja muslim mengambil keputusan untuk mengikuti program pembinaan Remas.

Adapun, dalam proses pengiriman pesan, Remas memanfaatkan media yang sering dan mudah di akses oleh remaja muslim yaitu yang media berbasis internet seperti medsos instagram, twitter, facebook. Selain itu untuk memberikan informasi yang lebih jelas, spesifik, dan personal serta kemudahan dalam mendapatkan feedback juga maka digunakanlah saluran pribadi seperti penjualan personal dan pemasaran langsung. Pemanfaatan saluran pribadi ini juga digunakan untuk meminimalisir adanya gangguan dalam pengiriman pesan.

Dari segi praktis diharapkan studi ini dapat menjadi referensi Remas di Indonesia dalam merumuskan komunikasi pemasaran program pembinaan berbasis model AIDA. Diharapkan juga dapat menjadi salah satu pendukung suksesnya upaya untuk mengaktifkan kembali Remas di Indonesia. Kemudian dari segi teoritis pun diharapkan dapat memperkaya konsep komunikasi pemasaran lembaga dakwah terutama Remas dengan pendekatan teori AIDA.

\section{Bibliografi}

Afifi, Subhan dan Muhammad Edy Susilo, "Pengembangan Komunikasi Pemasaran Sekolah", Jurnal IImu Komunikasi 13, no. 3 (2014) : 277-286. doi: https://doi.org/10.31315/jik.v12i3.1446

Ayub, Moh. E. , Muhsin MK, dan Ramlan Mardjoned. Manajemen Masjid. Jakarta: Gema Insani, 1996.

Budiman, Haris. "Kesadaran Beragama Pada Remaja Islam." Al Tadzkiyyah - Jurnal Pendidikan Islam 06 (2015): 16-26. doi: https://doi.org/10.24042/atjpi.v6i1.1474

Chrismardani, Yustina. "Komunikasi Pemasaran Terpadu : Implementasi Untuk UMKM." Jurnal NeO-Bis 8, no. 2 (2014): 176-189. doi: https://doi.org/10.21107/nbs.v8i2.472 
Dachlan, Muhammad. "Media Online dan Pembentukan Pemahaman Keagamaan Siswa di MAN 1 Ambon." Jurnal Mimikri - Jurnal Agama dan Kebudayaan 6, no. 2 (2020): 265276. doi: https://blamakassar.e-journal.id/mimikri/article/view/438

Fatimah, Siti. Konsep Pendidikan Remaja Muslim Menurut Abdullah Nashih Ulwan. Tesis Program Pascasarjana, Medan: UIN Sumatera Utara, 2018.

Febriani, Nufian S, dan Wayan Weda Asmara Dewi. Teori dan Praktis : Riset Komunikasi Pemasaran Terpadu. Malang: Universitas Brawijaya Press, 2018.

Hakim, Siti Nurina, dan Aliffatullah Alyu Raj. "Dampak Kecanduan Internet (Internet Addiction) Pada Remaja." Prosiding Temu IImiah X Ikatan Psikologi Perkembangan Indonesia. Semarang: Ikatan Psikologi Perkembangan Indonesia, 2017. 282.

Irwan, Andi Muhammad . "Pengaruh Faktor Psikologis, Pribadi, Sosial dan Budaya Terhadap Keputusan Pembelian Produk Fashion Secara Online (Studi Kasus Pada Konsumen PT. Lazada Indonesia di Kota Makassar). FORECASTING: Jurnal IImiah IImu Manajemen 1, no. 2 (2019) : 167-168. doi: https://stiemmamuju.e-journal.id/FJIIM/article/view/21

Jayanti, Rina Duwi. "Penyusunan Desain Instruksional Pada Pelatihan Anggota Remaja Masjid Assalafiyah Surabaya." Jurnal Inteleksia - Jurnal Pengembangan Ilmu Dakwah 01, no. 02 (2020): 261-279. doi: http://www.inteleksia.stidalhadid.ac.id/index.php/inteleksia/article/view/53 Johar, Diah Syafita, Srikandi Kumadji, dan M. Kholi. "Pengaruh AIDA (Attention, Interest, Desire, Action)." Jurnal Administrasi Bisnis 26, no. 1 (2015): 2. doi: https://media.neliti.com/media/publications/86248-ID-pengaruh-aida-attentioninterest-desire.pdf

Kemasjidan, Subdit. "Pedoman Pembinaan Remaja Masjid." SIMAS - Sistem Informasi Masjid. 19 Juni 2020. https://simas.kemenag.go.id/page/download/detail/5eebbfe6d3b78 (diakses Januari 14, 2021).

Kurniawan, Dani. "Komunikasi Model Laswell Dan Stimulus-Organism-Response Dalam Mewujudkan Pembelajaran Menyenangkan." Jurnal Komunikasi Pendidikan 2, no. 1 (2018): 60-68. doi: https://doi.org/10.32585/ikp.v2i1.65

Kurniawan, Syamsul. "Masjid dalam Lintasan Sejarah Umat Islam." Jurnal Khatulistiwa Journal of Islamic Studies 04, no. 03 (2014): 169-184. doi: 10.24260/khatulistiwa.v4i2.258

Lestari, Sinta Petri. "Hubungan Komunikasi Pemasaran dan Promosi dengan Keputusan Memilih Jasa Layanan Kesehatan (Studi Pada Rumah Sakit Islam Lumajang)." Jurnal Interaksi 04, no. 2 (2015): 139-147. doi: https://doi.org/10.14710/interaksi.4.2.139$\underline{147}$

Mangestuti , Retno, dan Rahmat Azis. "Pengembangan Spiritualitas Remaja : Mengapa Remaja Laki-laki Lebih Memerlukan Dukungan Keluarga dalam Pengembangan Spiritualitas." Jurnal Psikoislamika 14, no. 01 (2017): 31 - 37. doi: https://doi.org/10.18860/psi.v14i1.6500

Mulia, Sri Wahyuni, dan Azrul Zaid. "Relationship Of Emotional Maturity With Social Interaction Of Student In SMP N 1 Ranah Batahan Pasaman Barat." Jurnal Neo Konseling 1, no. 4 (2019): 1-8. doi: 10.24036/00158kons2019 
Najib, Moh. Farid, Deddy Saefuloh, Iwan Mulyawan, Eddy Syah Yahya, dan Tjetjep Djatnika.

"Peningkatan Kapasitas Lembaga Melalui Pengembangan Komunikasi Pemasaran Guna Mendorong Minat Donatur Dalam Berdonasi Pada Istana Yatim Dhu'afa". Jurnal DIFUSI 3, no. 1 (2020) : 17-29. doi: https://doi.org/10.35313/difusi.v3i1.1946

Nuwairah, Nabed. "Peran Keluarga dan Organisasi Remaja Masjid Dalam Dakwah Terhadap Remaja." Al Tadzkiyyah - Jurnal "Al-Hiwar" 03, no. 06 (2015): 1-12. doi: http://dx.doi.org/10.18592/al-hiwar.v3i6.1211

Poetra, Reza Riesnanda, dan Nevrettia Christantyawati. "Model AIDA : Pola Penggunaan Media Sosial dalam Meningkatkan Kepuasan Penjualan di Toko Online Goldies Hijab." Jurnal Komunikasi Profesional 1, no. 1 (2017): 22-36. doi: http://dx.doi.org/10.25139/jkp.v1i1.170

Rahmah, Itsna Fitria. "Etika Pergaulan Remaja Muslim yang Ramah Ditinjau dari Konsep Peace Education, Studi di SMA Islam Al Azhar 14 Semarang." Jurnal Pendidikan Madrasah 01, no. 02 (2016): 245-256. doi: http://ejournal.uinsuka.ac.id/tarbiyah/index.php/JPM/article/view/1217

Rizqa, Hasanul. "DMI Luncurkan Program 1 Kelurahan 1 Remaja Masjid." Republika.co.id. 18 Maret 2019. https://republika.co.id/berita/pojgap458/dmi-luncurkan-program-1kelurahan-1-remaja-masjid (diakses Januari 15, 2021).

Rumondor, Prasetio, dan Puspasari M. Y. Gobel. "Pola Pembinaan Kepribadian dan Keagamaan Remaja Masjid Al-Fatah Di Kelurahan Girian Indah Kecamatan Girian Kota Bitung." AlIzzah : Jurnal Hasil-Hasil Penelitian 14, no. 2 (2019): 1-16. doi: http://dx.doi.org/10.31332/ai.v14i2.1525

Samiudin. "Problematika Penulisan Proposal Skripsi." Jurnal Studi Islam 10, no. 1 (2015): 8297. doi: https://core.ac.uk/download/pdf/234800319.pdf

Santoso, Daniel Teguh Tri, dan Endang Purwanti. "Pengaruh Faktor Budaya, Faktor Sosial, Faktor Pribadi, dan Faktor Psikologis Terhadap Keputusan Pembelian Konsumen dalam Memilih Produk Operator Seluler Indoset-M3 di Kecamatan Pringapus Kab. Semarang." Jurnal Among Makarti 06, no. 12 (2013): 112-129. doi: https://jurnal.stieama.ac.id/index.php/ama/article/view/92

Sasongko, Agung. "Manajemen Remaja Masjid akan Diperkuat." Republica.co.id. 18 Maret 2019. https://www.republika.co.id/berita/pojx2×313/manajemen-remaja-masjidakan-diperkuat (diakses Januari 15, 2021).

Sholeh, Rahmat. Proses Hierarchy of Effect Model Dalam Komunikasi Pemasaran. Skripsi Program Sarjana, Yogyakarta: UIN Sunan Kalijaga, 2018.

Srisusilawati, Popon. "Kajian Komunikasi Pemasaran Terpadu dalam Mendorong Keputusan Pembelian Jasa Perbankan." Jurnal Ekonomi dan Keuangan Syariah 1, no. 1 (2017): 118. doi: https://doi.org/10.29313/amwaluna.v1i1.1993

Sumarwan, Ujang, dan Fandy Tjiptono. Strategi Pemasaran dalam Perspektif Perilaku Konsumen. Bogor: IPB Press, 2019.

Susanto, Agus. "Keputusan Stratejik Program Open Recruitment Remaja Masjid Al Akbar Surabaya 2014-2016." Tesis Program Pascasarjana, UIN Sunan Ampel, Surabaya, 2017. 
Syakib, Najmi. "Pembinaan Keagamaan Bagi Remaja Melalui Aktivitas Remaja Masjid Dalam Menumbuhkan Sikap Toleransi Antar Umat Beragama." Skripsi Program Sarjana, UIN Sultan Maulana Hasanuddin, Banten, 2019.

"Ubah Citra Remaja Masjid." Republika.co.id. 21 November 2014. https://www.republika.co.id/berita/koran/halaman-1/14/11/21/nfdhw99-ubah-citraremaja-masjid (diakses Agustus 6, 2018).

Waskito, Jati, dan Wahyono. “Upaya Mengurangi Skeptisisme Iklan Hijau Dalam Meningkatkan Perilaku Pembelian Produk Hijau." BENEFIT - Jurnal Manajemen dan Bisnis 1, no. 02 (2016): 107-119. doi: 10.23917/benefit.v1i2.3254

Yuniati, Yenni, Ani Yuningsih, dan Nurahmawati. "Konsep Diri Remaja dalam Komunikasi Sosial melalui "Smartphone"." Mimbar 31 - Jurnal Sosial dan Pembangunan, no. 2 (2015): 439 - 450. doi: https://doi.org/10.29313/mimbar.v31i2

Wulandari, Indah. "Menyiasati yang Muda Agar Giat di Kelompok Remaja Masjid." Republica.co.id. 24 Februari 2015. https://www.republika.co.id/berita/nk9ig1/menyiasati-yang-muda-agar-giat-dikelompok-remaja-masjid (diakses Januari 15, 2021).

Yuniati, Yenni, Ani Yuningsih, dan Nurahmawati. "Konsep Diri Remaja dalam Komunikasi Sosial melalui "Smartphone"." Mimbar 31 - Jurnal Sosial dan Pembangunan, no. 2 (2015): 439 - 450. doi: https://doi.org/10.29313/mimbar.v31i2 
Komunikasi Pemasaran untuk Progam Pembinaan Remaja Masjid 